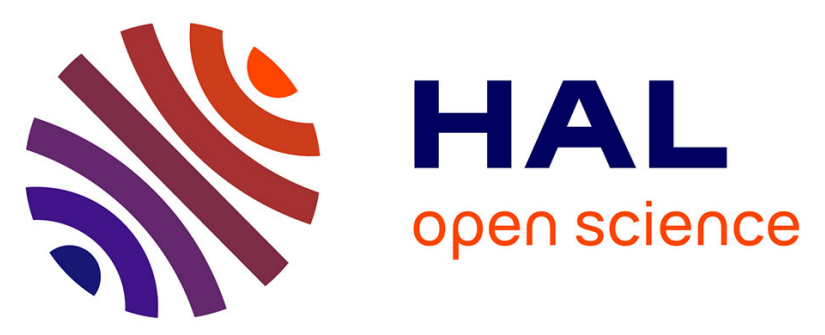

\title{
When tree rings behave like foam: moderate historical decrease in the mean ring density of common beech paralleling a strong historical growth increase
} Jean-Daniel Bontemps, Pierre Gelhaye, Gérard Nepveu, Jean-Christophe Hervé

\section{To cite this version:}

Jean-Daniel Bontemps, Pierre Gelhaye, Gérard Nepveu, Jean-Christophe Hervé. When tree rings behave like foam: moderate historical decrease in the mean ring density of common beech paralleling a strong historical growth increase. Annals of Forest Science, 2013, 70 (4), pp.329-343. 10.1007/s13595013-0263-2 . hal-00869316v2

\section{HAL Id: hal-00869316 \\ https://hal.science/hal-00869316v2}

Submitted on 20 May 2014

HAL is a multi-disciplinary open access archive for the deposit and dissemination of scientific research documents, whether they are published or not. The documents may come from teaching and research institutions in France or abroad, or from public or private research centers.
L'archive ouverte pluridisciplinaire HAL, est destinée au dépôt et à la diffusion de documents scientifiques de niveau recherche, publiés ou non, émanant des établissements d'enseignement et de recherche français ou étrangers, des laboratoires publics ou privés.

$$
\text { Copyright }
$$


When tree rings behave like foam: moderate historical decrease in the mean ring density of common beech paralleling a strong historical growth increase

\author{
Jean-Daniel BONTEMPS ${ }^{1,2 *}$, Pierre GELHAYE ${ }^{2,1}$, Gérard NEPVEU ${ }^{2,1}$, Jean-Christophe \\ HERVÉ ${ }^{3}$
}

${ }^{1}$ AgroParisTech, UMR 1092 INRA/AgroParisTech LERFoB (Laboratoire d'Etude des Ressources Forêt-Bois), 14 rue Girardet, F-54000 Nancy

${ }^{2}$ INRA, Centre de Nancy-Lorraine, UMR 1092 INRA/AgroParisTech LERFoB (Laboratoire d'Etude des Ressources Forêt-Bois), F-54280 Champenoux

${ }^{3}$ Institut National de l'Information Géographique et Forestière, IGN, Service de recherche sur les méthodes de l'Inventaire Forestier, 11 rue de l'Ile de Corse, F-54000 Nancy

* corresponding author: AgroParisTech, LERFoB, équipe Ecologie Forestière, 14 rue Girardet, 54000 Nancy, France. jdbontemps.agroparistech@gmail.com, 0383396875

Running head: Historical decrease in wood density of common beech 


\begin{abstract}
Context. While historical increases in forest growth have been largely documented, investigations on historical wood density changes remain anecdotic. They suggest possible density decreases in softwoods and ring-porous hardwoods, but are lacking for diffuse-porous hardwoods.

Aims. To evaluate the historical change in mean ring density of common beech, in a regional context where a ring-porous hardwood and a softwood have been studied, and assess the additional effect of past historical increases in radial growth ( $+50 \%$ over 100 years), resulting from the existence of a positive ring size-density relationship in broadleaved species.

Methods. 74 trees in 28 stands were sampled in Northeastern France to accurately separate developmental stage and historical signals in ring attributes. First, the historical change in mean ring density at $1.30 \mathrm{~m}$ (X-ray microdensitometry) was estimated statistically, at constant developmental stage and ring width. The effect of past growth increases was then added to assess the net historical change in wood density.

Results. A progressive centennial decrease in mean ring density of $-55 \mathrm{~kg} \cdot \mathrm{m}^{-3}(-7.5 \%)$ was identified $(-10 \%$ following the most recent decline). The centennial growth increase induced a maximum $+25 \mathrm{~kg} \cdot \mathrm{m}^{-3}$ increase in mean ring density, whose net variation thus remained negative $\left(-30 \mathrm{~kg} \cdot \mathrm{m}^{-3}\right)$.

Conclusions. This finding of a moderate but significant decrease in wood density that exceeds the effect of the positive growth change extends earlier reports obtained on other wood patterns in a same regional context and elsewhere. Despite their origin is not understood, such decreases hence form an issue for forest carbon accounting.
\end{abstract}

Keywords: Fagus sylvatica; wood density; X-ray microdensitometry; historical change, ring width, growth change 


\section{INTRODUCTION}

Long-term increases in the height and radial growth of boreal and temperate forests, of a magnitude of several tens up to $100 \%$ over one century, have been reported over the last decades, and up to recently (of which Spiecker et al. 1996; Boisvenue and Running 2006; Bontemps et al. 2012; Sharma et al. 2012). By contrast, far less is known on possible historical trends in wood density (Nepveu 1999), in spite of its importance to wood quality, and biomass/carbon sequestration issues. The anecdotic available material suggests density decreases of a moderate magnitude of -5 to $-10 \%$, as evidenced on conifers in boreal and temperate contexts (Conkey 1988 on maximum latewood density and Franceschini et al. 2010 on mean ring density in mid-elevational temperate contexts; Briffa et al. 1998 on maximum latewood density at the boreal tree line) and on a ring-porous broadleaved species (Bergès et al. 2000 on mean ring density of sessile oak in a temperate area). No study has ever been conducted on diffuse-porous broadleaved species, despite this wood pattern is widespread among angiosperms, including Fagaceae (genus Fagus), Betulaceae (Betula, Carpinus, Alnus), Aceraceae and Tiliaceae (Jacquiot et al. 1973).

Some of the reported decreases were identified on species that also experienced increased growth over time (Bergès et al. 2000 on Sessile oak; Badeau et al. 1996 and Franceschini et al. 2010 on Norway spruce), which has two implications. First, a temporal negative trade-off between radial growth and density may occur, which could be envisioned as a partial foam effect (pressure dampened on a foam makes it bigger and less dense). Second, trends in biomass productivity and carbon sequestration would be less than usually inferred from changes on a volume scale.

However, there is inherent difficulty in diagnosing and interpreting trends on ring density indicators. In addition to the effect of developmental stage, ring density depends on growth rate (a dependence hereafter named ring size-density relationship), and hence on both silviculture (Gonçalves et al. 2004; Guilley et al. 2004; Mörling 2002; Zobel 1992) and environment-related growth changes. Statistical modelling evaluations that filter out the effect of growth (Franceschini et al. 2010) are thus required, to ensure that silvicultural trends (Spiecker 1999) or decennial disturbances (e.g. management-induced growth suppressions, Mäkinen 1997) do not affect the historical signal evidenced in wood density. Nevertheless, a parallel estimate of environment-related radial growth trends and their additional impact on ring wood density, resulting from the ring size-density relationship, is needed as soon as the purpose is to deliver an integrated historical overview of wood density variations, an aspect never covered in previous studies.

In this respect, the ring size-density relationship varies widely in sign/magnitude among wood patterns, and this has contrasted consequences on these historical trends:

(i) in softwoods (homoxylous wood), the relationship between mean ring density and ring width varies from null (Karlman et al. 2005; Peltola et al. 2007 on Scots pine) to negative (Venet 1963 on Silver fir; Rozenberg et al. 2001 on Douglas fir; Karlman et al. 2005 on European larch), and is among the strongest in Norway spruce ( -10 to $-20 \mathrm{~kg} \cdot \mathrm{m}^{-3} \cdot \mathrm{mm}^{-1}$ ring width, Franceschini et al. 2010). Therefore, 
the $-5 \%$ decrease in mean ring density over one century evidenced at constant ring size by Franceschini et al. on Norway spruce implies an even stronger historical decrease, in a context where growth trends are positive (Badeau et al. 1996);

(ii) in broadleaved species, the distribution of vessels along the rings features the relationship. In ringporous hardwoods where vessels form continuous initial cell ranks and are then much smaller and disseminated along the ring, the relationship is strongly positive $\left(+50 \mathrm{~kg} \cdot \mathrm{m}^{-3} \cdot \mathrm{mm}^{-1}\right.$ on pedunculate and sessile oaks in Rao et al. 1997 and Bergès et al. 2000). On sessile oak, Bergès et al. (2000) evidenced a $+66 \%$ increase in ring size over one century, inducing an increase in mean ring density of $+25 \mathrm{~kg} \cdot \mathrm{m}^{-3}$. However, a counteracting direct decrease of $-29 \mathrm{~kg} \cdot \mathrm{m}^{-3}(-4 \%)$ in mean ring density, estimated at constant ring width, resulted in a fair stability of mean ring density over the century;

(iii) in diffuse-porous hardwoods, wood pattern varies from being homogeneous along the ring (e. g. in Aceraceae, Betulaceae or Salicaceae) to most often differentiated in a radial direction, with scarcer vessels of a smaller diameter (Jacquiot et al. 1973). This leads to a null (Zhang 1995 in Betula and Populus genus) to weak positive relationship (Nepveu 1981a on Fagus sylvatica). While the effect of growth changes may thus be lower than on ring-porous hardwoods, there is no report available for this wood type.

In a lacking context regarding wood density trends, and on diffuse-porous hardwoods in particular, we conducted a study on the mean ring density of common beech (Fagus sylvatica L.) taken as a model species for this wood type. The species was studied in North-eastern France, to complement the studies performed by Bergès et al. (2000) on a ring-porous hardwood, and Franceschini et al. (2010) on a softwood, in a comparable historical environment. As a further interest, studies conducted on the ring density of common beech are limited. The existence of a ring size-density relationship is controversial, suggesting contrasted consequences of the growth increases already reported for that species (no relationship found by Polge 1973 and Keller et al. 1976, a positive relationship in Nepveu 1981a, and a weak and negative relationship - but exhibiting a strong between-tree variation - in Bouriaud et al. 2004). The single statistical modelling analysis of ring density available to date is that of Bouriaud et al. (2004).

The analysis reported here was conducted on a sample specifically designed to investigate historical trends (Bontemps et al. 2009). It relies on pairs of neighbour stands of successive generations growing in the same site conditions (Lebourgeois et al. 2000). Positive growth changes of a magnitude of $+50 \%$ over the 20th century have been evidenced on common beech, and these were strongly similar in dominant height growth and radial growth at 1.30m height (Bontemps et al. 2010), suggesting that silvicultural trends in radial growth are unlikely. Mean ring density was studied based on X-ray microdensitometric measurements on strips taken at $1.30 \mathrm{~m}$.

The objectives of this study were as follows: (i) to estimate the historical variations in mean ring density at constant ring size and developmental stage (distance or age from the pith), based on a statistical modelling approach allowing account of the between-tree variability often reported in these relationships. An aspect was to verify the existence of the ring size-density relationship. The 
hypothesis tested was that a decrease in mean ring density would also affect this diffuse-porous hardwood, (ii) to estimate the net historical variations in mean ring density resulting from the direct historical variations evidenced above, and the additional contribution of historical changes in ring size at $1.30 \mathrm{~m}$ evidenced on this sample (Bontemps et al. 2010), resulting from the ring size-density relationship. The hypothesis tested was that either compensation or a partial foam effect should also affect this species.

\section{MATERIALS AND METHODS}

\section{Sampling design}

The sampling design is presented in details in Bontemps et al. $(2009,2010)$. Its main features are as follows: the identification of a historical signal in mean ring density relies on comparing rings between stands of successive generations at a given developmental stage, while ensuring a strict control of site. To that end, the paired-plots method (Bontemps et al. 2009, Lebourgeois et al. 2000) was applied, and 14 pairs of young/old (64.6/140.1 yrs, SD: 15.0/20.2 yrs, respectively) neighbour stands (mean distance: $160 \mathrm{~m}$ ) were sampled in North-eastern France in 1998. These were located at a mean elevation of $370 \mathrm{~m}$ (SD: $50 \mathrm{~m}$ ). A post-sampling control of within-pair site conditions was ensured through in situ measurements of vegetation, complemented by soil analyses. Stand pairing proved to be successful, as no systematic difference in environmental indicators was found (Bontemps et al. 2009). In each stand, 3 dominant trees were sampled in a 0.06 ha circular plot following the protocol of Duplat and Tran-ha (1997). In total 84 trees were sampled.

\section{Ring density measurements}

Disks were sampled at $1.30 \mathrm{~m}$ on each tree (Bontemps et al. 2010). Ten deteriorated disks at the time of measurements were discarded. Two $2 \mathrm{~mm}$-thick opposed strips were sawn over each disk in a random direction, and were dried at a $12 \%$ relative humidity. X-ray microdensitometric measurements were conducted following Polge and Nicholls (1972). Films were digitised at a 1000 dpi resolution, providing a measurement resolution of $25 \mu \mathrm{m}$ in a radial direction (CERD software, Mothe et al. 1998). For each strip, a density correction was performed by scaling to a gravimetric measure of strip density. A mean ring density was computed for each ring. An inter-dating procedure was conducted with reference to independent inter-dated ring width measurements performed on the same disks (Bontemps et al. 2010). Mean ring density annual chronologies were averaged over the two strips of each tree. The age from the pith (hereafter cambial age), calendar year of formation, and tree radius at the time of ring formation (distance from the pith) were then defined for each ring. As ring density chronologies were highly variable in juvenile wood, the first 20 rings of each tree were removed (Nepveu 1981b). In total, 5759 rings on 74 trees were collected. 


\section{Exploratory data analysis}

Sample statistics for the main variables and their correlations with mean ring width density are provided in Table 1. Correlations between mean ring density and cambial age/ring width were found negative/positive, respectively (Table 1). The correlation with ring width was weak but highly significant. A negative correlation $(-0.297)$ with calendar year was also identified.

In addition, considerable between-tree variation in these correlations was found: that between ring width and ring density varied between -0.65 and +0.80 (average 0.16 ), and was negative for 20 out of 74 trees. That between cambial age and ring density ranged between -0.90 and +0.67 (average -0.40 ) and was positive for 7 trees.

The relationships with cambial age (Figure 1a) and tree radius (not presented) showed a convexity. The relationship between mean ring density and ring width was concave and found to be depending on cambial age/tree radius (i.e. an interaction; Figure 2), and was steeper at later developmental stage. On average, ring density was clearly lower in the younger stand generation than in the older one (Figure 1a).

\begin{tabular}{cccccc}
\hline & $\begin{array}{c}\text { Mean ring density } \\
\left(\mathrm{kg} \cdot \mathrm{m}^{-3}\right)\end{array}$ & $\begin{array}{c}\text { Cambial age } \\
(\text { years })\end{array}$ & $\begin{array}{c}\text { Tree radius } \\
(\mathrm{mm})\end{array}$ & $\begin{array}{c}\text { Ring width } \\
(\mathrm{mm})\end{array}$ & Calendar year \\
\hline Mean & 730.0 & 71.0 & 146.5 & 2.2 & 1947.9 \\
$\mathrm{SD}$ & 54.8 & 36.7 & 72.8 & 1.0 & 36.7 \\
Correlation & - & -0.444 & -0.425 & 0.170 & -0.297 \\
$p$ & - & $<10^{-4}$ & $<10^{-4}$ & $<10^{-4}$ & $<10^{-4}$ \\
\hline
\end{tabular}

Table 1 Sample statistics of the different ring variables and correlations with mean ring density. The sample comprises 5759 rings. SD: standard-deviation, $p$ : p-value of the Pearson's test of correlation. 

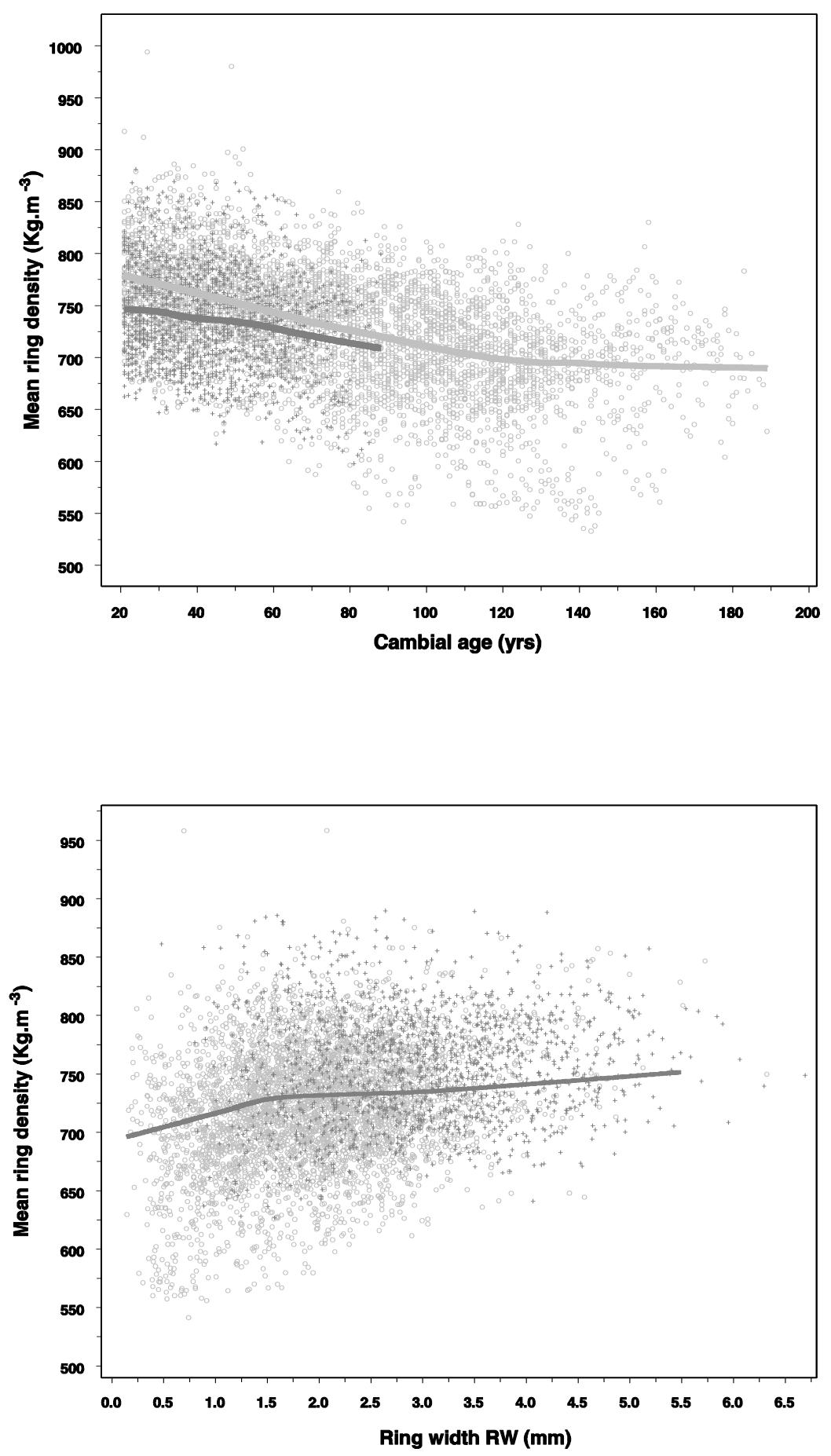

Fig. 1 Relationships between mean ring density and cambial age (a) or ring width (b). Open light grey circles: rings of older tree generation, dark grey pluses: younger generation. In figure 1a, observations were smoothed (loess function) by tree generation to highlight the between-generation difference in mean ring density at constant cambial age. In Figure $1 \mathrm{~b}$, the change in radial growth between the two tree generations is discernible, and smoothing was common to all observations. Convex and concave curvatures were depicted in these successive relationships. 


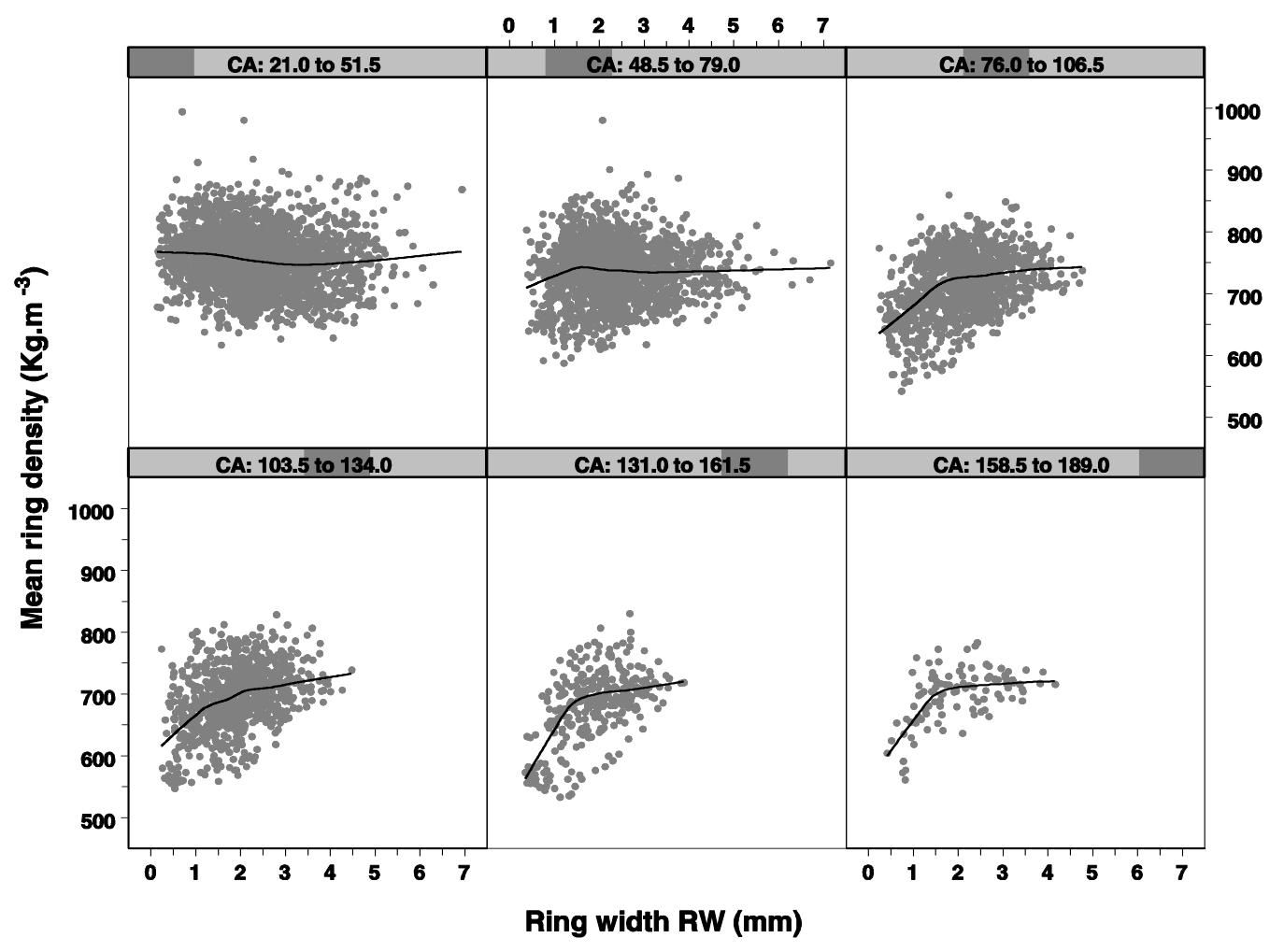

Fig. 2 Relationship between mean ring density and ring width (RW) for different classes of cambial age (CA). Cambial ages below 20 years were removed to exclude juvenile wood (see Materials). The relationship between mean ring density and ring width was highlighted in this diffuse-porous wood pattern. The relationship intensity was found to increase with greater cambial ages (flat at younger ages), suggesting to introduce a multiplicative interaction between ring width $R W$ and developmental stage in the models fitted.

\section{Historical change in mean ring density at constant developmental stage and ring width: modelling strategy}

The statistical modelling approach was intended to estimate historical variations in wood density (effect of calendar year), at a constant developmental stage (cambial age or tree radius) and ring width. A related objective was therefore to test the effect of ring width on ring density. While developmental stage is predominantly represented by cambial age in modelling approaches of ring density (Bouriaud et al. 2004; Franceschini et al. 2010; Guilley et al. 1999), functional and allometric studies of tree biomechanics suggest that tree size may be of primary importance (King et al. 2006; Rosell and Olson 2007). In addition, trees of identical age growing in different site conditions, or at different periods in a context of environmental changes, will show different sizes, and these references will therefore differ. Their respective predictive accuracy on mean ring density was tested. 
The dataset is composed of longitudinal annual data. In addition, age-density and growth-density relationships exhibit considerable between-tree variation in tree species (Bouriaud et al. 2004 on common beech). The tree level has further been shown to exhibit the highest variability in wood density among hierarchical structural levels including site, stand, or height within the tree (Guilley 2000 and Le Moguédec et al. 2002, both on sessile oak). Mixed-effects models (Davidian and Giltinan 1995) were therefore fitted, including random tree effects when these were significant. Models were fitted by maximum likelihood (L) using the linear and non-linear mixed-effects model algorithms of Lindström and Bates (1990), with functions lme and nlme of S-PLUS software (Pinheiro and Bates 2000). Nested models were compared using the likelihood ratio Chi-2 test (LRT statistics, Pinheiro and Bates 2000). Non-nested models were compared using the AIC (AIC $=-2(\ln \mathrm{L}+\mathrm{p})$ where $\mathrm{p}$ is the number of parameters) intended to be as small as possible.

\section{Statistical modelling steps}

Step 1. Test and selection of the different effects

Based on the exploratory data analysis, an initial modelling framework was formulated as follows:

$$
D_{\mathrm{it}}=\left(\mathrm{a}_{0}+\mathrm{a}_{\mathrm{i}}\right)+\left(\mathrm{b}_{0}+\mathrm{b}_{\mathrm{i}}\right) S D_{\mathrm{it}}+\left[\left(\mathrm{e}+\mathrm{e}_{\mathrm{i}}\right)+\left(\mathrm{f}+\mathrm{f}_{\mathrm{i}}\right) S D_{\mathrm{it}}\right] R W_{\mathrm{it}}+\mathrm{d} t+\varepsilon_{\mathrm{it}}
$$

where $D$ stands for mean ring density, $S D$ is a proxy of developmental stage, $R W$ is ring width, and $t$ is a re-parameterization of calendar year such that $t=$ date -1900 (hence 1900 is the reference date for measuring a historical change). Tree, and ring at time $t$ within the tree, are indexed by $\mathrm{i}$ and $\mathrm{t}$, respectively. Parameters $a_{\mathrm{i}} \ldots f_{\mathrm{i}}$ are tree random effects on the fixed parameters. Further assumptions are: $\varepsilon_{\text {it }} \sim \mathrm{N}\left(0, \sigma^{2}\right)$ and $\theta \sim \mathrm{N}\left(\theta_{0}, \mathrm{G}\right)$ where $\theta_{0}=\left(\mathrm{a}_{0}, \mathrm{~b}_{0}, \mathrm{e}_{0}, \mathrm{f}_{0}\right)$ is the vector of fixed parameters, and $\theta=$ $\left(a_{i}, b_{i}, e_{i}, f_{i}\right)$ is the vector of associated random parameters, $G$ is their symmetric variance-covariance matrix, and $\mathbf{N}$ corresponds to the multidimensional Gaussian law. Since we sought to detect the mean historical trend in wood density over the sample, parameter $d$ only had a fixed component.

First, developmental stage ( $S D$ in Eq. 1) was represented by cambial age (CA, model M1) and tree radius $(R$, model $\mathrm{M} 2)$, successively. The linear effect of calendar year was tested once the most predictive effect for developmental stage was retained (model M3).

\section{Step 2. Mathematical representation of the effects of developmental stage and ring width}

The curvatures detected in the relationships with developmental stage (Figure 1a) and ring width (Figures 1b and 2) were then included in the following generalisation:

$$
D_{\mathrm{it}}=\left(\mathrm{a}_{0}+\mathrm{a}_{\mathrm{i}}\right)+\left(\mathrm{b}_{0}+\mathrm{b}_{\mathrm{i}}\right) f_{1}\left(S D_{\mathrm{it}}, \mathrm{c}\right)+\left[\left(\mathrm{e}+\mathrm{e}_{\mathrm{i}}\right)+\left(\mathrm{f}+\mathrm{f}_{\mathrm{i}}\right) S D_{\mathrm{it}}\right] f_{2}\left(R W_{\mathrm{it}}\right)+\mathrm{d} t+\varepsilon_{\mathrm{it}}
$$

where: 
- $\quad f_{1}$ is an asymptotic function of developmental stage, namely a hyperbolic function $\left(f_{1}=(\mathrm{b}+\mathrm{bi})\right.$ $S D /(S D+\mathrm{c})$ with $\mathrm{b}<0$, model M4.1) or a negative exponential function $\left(f_{1}=((\mathrm{b}+\mathrm{bi}) \exp (-\right.$ $S D / c)$ with $\mathrm{b}>0$, model M4.2). Since these forms were non-linear in parameter $\mathrm{c}$, we used the nlme procedure of S-PLUS software. No random effect was tested on parameter $\mathrm{c}$.

- $f_{2}$ was represented by alternative forms of increasing curvature, namely $: f_{2}=1 / R W$ (model M5.1), ln $R W$ (model M5.2) or $R W^{0.5}$ (model M5.3), starting from the most accurate previous model (M4.1 or M4.2).

\section{Step 3. Simplification of the model, estimation of historical variations in mean ring density}

Once representations for $f_{1}$ and $f_{2}$ were selected, we investigated whether the random structure of the model could be simplified regarding parameters e and $\mathrm{f}$ in particular (the final model was denoted model M6).

Up to model M6, a mean historical trend in mean ring density was estimated (parameter d). In line with Bontemps et al. (2009, 2010), we estimated its historical variations of decennial range. We tested a polynomial-type effect of calendar year $\left(f_{3}(t)\right.$, model M7) using a cubic-spline function (property of minimal curvature, restricting excessive oscillations, Lange 1999), which is a piecewise continuous polynomial without any sudden variation in slope over the time period covered. We selected a regular inter-node of 15 years, as was done on radial growth in Bontemps et al. (2010). The associated model was as follows:

$$
D_{\mathrm{it}}=\left(\mathrm{a}_{0}+\mathrm{a}_{\mathrm{i}}\right)+\left(\mathrm{b}_{0}+\mathrm{b}_{\mathrm{i}}\right) f_{1}\left(S D_{\mathrm{it}}, \mathrm{c}\right)+\left[\left(\mathrm{e}+\mathrm{e}_{\mathrm{i}}\right)+\left(\mathrm{f}+\mathrm{f}_{\mathrm{i}}\right) S D_{\mathrm{it}}\right] f_{2}\left(R W_{\mathrm{it}}\right)+f_{3}(t, \mathrm{P})+\varepsilon_{\mathrm{it}}
$$

And:

$$
f_{3}(t, \mathrm{P})=\mathrm{d}_{1} t+\mathrm{d}_{2} t^{2}+\mathrm{d}_{3} t^{3}+\sum_{k=1}^{\mathrm{k} 1} \mathrm{p}_{k}(\max (t-n \mathrm{k}, 0))^{3}+\sum_{k=0}^{\mathrm{k} 2} \mathrm{pm}_{k}(\min (t+n \mathrm{k}, 0))^{3}
$$

where $P=\left(d_{1}, d_{2}, d_{3}, p_{1} \ldots p_{k 1}, p m_{1} \ldots m_{k 2}\right)$ is the vector of fixed parameters of the spline function, $t=$ date -1900 , and $n=15$ (inter-node), $\mathrm{k}_{1}=6$ et $\mathrm{k}_{2}=2$.

\section{Net historical change in mean ring density including the historical change in radial growth}

The historical trend/variations in mean ring density estimated by models M6/M7 were performed at constant ring width. In order to deliver an integrated evaluation of the historical change in ring density, we combined the latter trend with the additional one resulting from the historical radial growth increase (Bontemps et al. 2010) and propagating to mean ring density due to the positive ring growthdensity relationship evidenced (see Results),. In the following, this estimation is termed 'net historical variation', or 'change'. The model of mean ring density for the 'average' tree was used (only fixed parameters were considered). Tree size was kept constant over time. Since the single term $R \cdot R W^{0.5}$ 
was retained for the interaction, the historical variation in mean ring density over any time interval $[0$, t] starting in the year 1900, was thus written (Eq. 3) as:

$$
\Delta D(t)=D_{t}-D_{0}=f_{3}(t, \mathrm{P})+\mathrm{f} R\left(R W(t)^{0.5}-f_{2}\left(R W(0)^{0.5}\right)\right)
$$

In Bontemps et al. (2010) the radial increment of dominant trees was represented by a multiplicative model (Table 2) of the effects of site fertility (parameter S), developmental stage (sigmoid growth function of dominant tree radius, $\left.f_{4}(R)\right)$ and calendar year $(g(t)$ also represented by either a linear or a cubic spline function of year with an internode of 15 years, and such that $g(0)=1$ ):

$$
R W(t)=\mathrm{S} f_{4}(R) g(t)
$$

The average site conditions over the sample (mean value of $\mathrm{S}, \mathrm{S}_{\mathrm{m}}$ ) were retained. Hence, the net historical variation in mean ring density is given by:

$$
\Delta D(t)=f_{3}(t, \mathrm{P})+\mathrm{f} \mathrm{S}_{\mathrm{m}}^{0.5} R\left(f_{4}(R)\right)^{0.5}\left(g(t)^{0.5}-1\right)
$$

The assessment was conducted with both linear (mean trend) and cubic-spline (decennial variations) functions of calendar year, estimated on both mean ring density (Table 3, models M6 and M7) and radial growth (Bontemps et al. 2010, Table 2) data. The sample range was selected for dominant radius $(5$ to $40 \mathrm{~cm})$.

\section{RESULTS}

\section{Historical change in mean ring density at constant developmental stage and ring width}

Comprehensive details on the statistical modelling steps are provided in Online Resource 1 and in Table 3, and are summarized.

Modelling step 1. The effects of cambial age CA (negative) and the interaction $C A . R W$ (positive) were found highly significant. Strong between-tree variations in the $C A-D$ and $R W-D$ relationships (associated random effects) were identified (M1). Tree radius $R$ was found to outperform $C A$ as a proxy for developmental stage and was retained (M2). A negative and very significant linear effect of calendar year on mean ring density was found $\left(-32 \mathrm{~kg} \cdot \mathrm{m}^{-3}\right.$ over the 20 th century, M3, Table 3).

Modelling step 2. The hyperbolic effect of R (M4.1) significantly improved the model accuracy. The gain obtained with the exponential formulation was greater and was retained (M4.2). By accounting 


\begin{tabular}{cccc}
\hline & General model & $R W(t)=\mathrm{S}_{\mathrm{m}} \cdot(R / \mathrm{K})^{\mathrm{m}} /(1-\mathrm{m}+\mathrm{m}(R / \mathrm{K})) \cdot g(t)$ \\
\hline $\mathbf{S}_{\mathbf{m}}\left(\mathrm{mm} \cdot \mathrm{yr}^{-1}\right)$ & $\mathbf{~ a . ~}$ & Parameter estimates with linear effect of calendar year: $g(t)=\left(1+\mathrm{d}_{1} \cdot t\right)$, with $t=d a t e-1900$ \\
2.46 & 70.8 & $\mathbf{m}(-)$ & 0.469 \\
\hline
\end{tabular}

b. Parameter estimates with cubic-spline effect of calendar year: identical to Eq. 4 except that $\mathrm{k} 2=1$ (no parameter $\mathrm{pm}_{2}$ )

\begin{tabular}{cccccccccccccc}
$\begin{array}{c}\mathbf{S}_{\mathbf{m}} \\
\left(\mathrm{mm} . \mathrm{yr}^{-1}\right)\end{array}$ & $\mathbf{K}$ & $\mathbf{m}$ & $\mathbf{d}_{\mathbf{1}} \mathbf{x 1 0}^{-\mathbf{2}}$ & $\mathbf{d}_{\mathbf{2}} \mathbf{x} \mathbf{1 0}^{-4}$ & $\mathbf{d}_{\mathbf{3}} \mathbf{\times} \mathbf{1 0}^{-\mathbf{4}}$ & $\mathbf{p}_{\mathbf{1}}{ }^{\mathbf{a}}$ & $\mathbf{p}_{\mathbf{2}}$ & $\mathbf{p}_{\mathbf{3}}$ & $\mathbf{p}_{\mathbf{4}}$ & $\mathbf{p}_{\mathbf{5}}$ & $\mathbf{p}_{\mathbf{6}}$ & $\mathbf{p m}_{\mathbf{0}}$ & $\mathbf{p m}_{\mathbf{1}}$ \\
2.41 & 73.4 & 0.469 & 0.75 & 8.40 & -28.83 & 20.65 & 53.64 & -93.00 & 100.90 & -174.73 & 719.78 & 64.55 & -70.37 \\
\hline
\end{tabular}

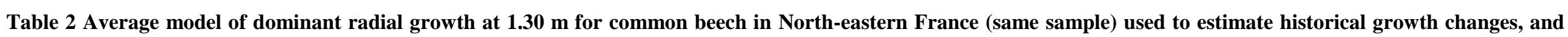

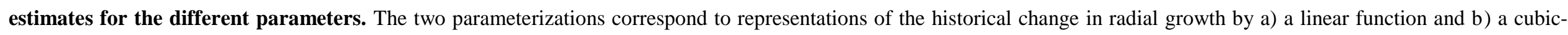

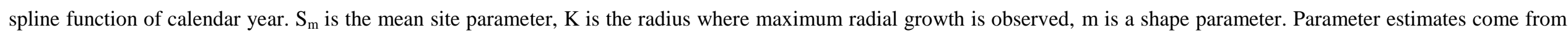
Table 2 of Bontemps et al. 2010. ${ }^{\text {a }}$ for parameters $\mathrm{p}_{2}$ to $\mathrm{pm}_{1}$, scales and units are identical to those of $\mathrm{p}_{1}$. 
for this $R-D$ relationship convexity, the magnitude of the historical trend logically increased $(-70 \mathrm{~kg}$. $\mathrm{m}^{-3}$ over the 20th century), corresponding to a $-10 \%$ decrease relative to the sample mean. The curvature of the $R W-D$ relationship was also confirmed, and the most accurate model was obtained with the power function of $R W\left(R W^{0.5}, \mathrm{M} 5.3\right)$. The historical trend estimated on mean ring density reached $-65 \mathrm{~kg} \cdot \mathrm{m}^{-3}$ over the 20th century.

Modelling step 3. Over-parameterization in the interaction between $R$ and $R W$ effects was observed in the previous steps. A test of different model parameterizations led to maintain the multiplicative effect $R . R W^{0.5}$ and remove the pure effect of $R W$ (M6). The number of model parameters was reduced from 17 to 12 , following the simplification of the variance-covariance matrix of random effects. The historical trend estimate reached $-55 \mathrm{~kg} \cdot \mathrm{m}^{-3}$ over 100 years. Accounting for decennial fluctuations in mean ring density (cubic-spline function of year, $f_{3}$ of Eq. 3, M7) led to a significantly more accurate model than M6. Residuals of model M7 did not reveal any further bias. The test of normality was also satisfied.

The historical variations in mean ring density (M7) and the average trend (M6) are plotted in Figure 3. A regular decrease in mean ring density was emphasized over the century, and even in the late 19th century, with a magnitude $-75 \mathrm{~kg} \cdot \mathrm{m}^{-3}$ at the end century relative to 1900 , corresponding to a $-10.3 \%$ decrease relative to the sample average $\left(730 \mathrm{~kg} \cdot \mathrm{m}^{-3}\right)$. This decrease significantly departed from zero since the early 1930s. Nevertheless, positive and negative temporary deviations in mean ring density over the 20th century were uncovered by the spline function, and these were also detected in the observations (Figure 3): positive anomalies in the 1910s, 1940s and 1980s accounted for the positive oscillations captured by the spline function, while negative anomalies in the 1920s-1930s, 1960s and 1990s accounted for the negative ones. The recent and quite sharp decrease in mean ring density accounted for the difference with the average trend of $-0.55 \mathrm{~kg} \cdot \mathrm{m}^{-3} \cdot$ year $^{-1}(-7.5 \%$ relative decrease). Some anomalies were however not reflected in the spline fit, such as more discrete positive events in the late 1950s-early 1960s, and in the late 1970s.

\section{Net historical change in mean ring density including the historical increase in radial growth}

The historical trend in annual radial growth is plotted in Figure 4a. An increase in annual radial growth of up to $+50 \%$ was observed in the 1990 s ( $+38 \%$ on average). Negative anomalies were observed in the 1940s and 1990s. The historical variations in mean ring density and radial growth were compared (Figure 4b) after standardisation by a 3rd-order polynomial and scaling. The comparison revealed their noticeable synchronicity in the decades 1890s, 1910-1920s and 1980s. Between the 1940s and 1970s, however, variations of lower amplitude were of opposed sign as captured by the cubic-spline functions.

When the linear historical trend in mean ring density and that resulting from the linear radial growth trend were combined (Table 2 and M6 in Table 3), the net change in mean ring density was found to be almost linear at a fixed tree radius, and ranged between $-50 \mathrm{~kg} \cdot \mathrm{m}^{-3}$ at a radius of $5 \mathrm{~cm}$ to $-31 \mathrm{~kg} \cdot \mathrm{m}^{-3}$ at a radius of $40 \mathrm{~cm}$ (Figure 5), over the 20th century. The effect of increasing radial growth on mean 


\begin{tabular}{|c|c|c|c|c|c|c|c|c|c|c|c|c|c|c|c|}
\hline \multirow[b]{3}{*}{ Model } & \multicolumn{9}{|c|}{ Parameter estimates } & \multicolumn{6}{|c|}{ Model statistics } \\
\hline & \multicolumn{5}{|c|}{ Fixed effects } & \multicolumn{4}{|c|}{ Random effects } & \multirow[b]{2}{*}{$\underset{\mathrm{kg} \cdot \mathrm{m}^{-3} \cdot \mathrm{mm}^{-3,2}}{\boldsymbol{\sigma}^{\mathrm{b}}}$} & \multirow[b]{2}{*}{$\underset{\mathrm{kg} \cdot \mathrm{m}^{-3}}{\sigma}$} & \multirow[b]{2}{*}{$\mathbf{p}^{\mathrm{c}}$} & \multirow[b]{2}{*}{$\ln \mathrm{L}$} & \multirow[b]{2}{*}{ AIC } & \multirow[b]{2}{*}{$p(\text { LRT })^{d}$} \\
\hline & $\underset{\mathrm{kg} \cdot \mathrm{m}^{-3}}{\mathbf{a}}$ & $\underset{\mathrm{kg} \cdot \mathrm{m}^{-3}}{\mathbf{b}}$ & $\underset{\mathrm{mm}}{\mathbf{c}}$ & $\begin{array}{c}\mathbf{d} \\
\mathrm{kg} \cdot \mathrm{m}^{-} \\
\text {. } \mathrm{yr}^{-1} \\
\end{array}$ & $\begin{array}{c}\mathbf{e}^{\mathbf{a}} \\
\mathrm{kg} \cdot \mathrm{m}^{-} \\
{ }^{3} \cdot \mathrm{mm}^{-1}\end{array}$ & $\underset{\mathrm{kg} \cdot \mathrm{m}^{-3} \cdot \mathrm{mm}^{-3.2}}{\mathbf{f}}$ & $\underset{\mathrm{kg} \cdot \mathrm{m}^{-3}}{\sigma^{\mathrm{b}}}$ & $\underset{\mathrm{kg} \cdot \mathrm{m}^{-3}}{\sigma^{\mathrm{b}}}$ & $\begin{array}{c}\sigma_{\mathrm{e}}^{\mathrm{b}} \\
\mathrm{kg} \cdot \mathrm{m}^{-} \\
{ }^{3} \cdot \mathrm{mm}^{-1}\end{array}$ & & & & & & \\
\hline \multirow[t]{2}{*}{ M1 } & 724.6 & -1.2 & - & - & -4.4 & 0.23 & 39.9 & 0.6 & 15.2 & 0.22 & 26.3 & 15 & -27375.2 & 54780.4 & \\
\hline & $<10^{-4}$ & $<10^{-4}$ & - & - & 0.051 & $<10^{-4}$ & & & & & & & & & \\
\hline \multirow[t]{2}{*}{ M2 } & 729.6 & -0.6 & - & - & -6.5 & 0.12 & 37.9 & 0.3 & 16.4 & 0.12 & 26.1 & 15 & -27342.0 & 54714.1 & \\
\hline & $<10^{-4}$ & $<10^{-4}$ & - & - & 0.006 & $<10^{-4}$ & & & & & & & & & \\
\hline \multirow[t]{2}{*}{ M3 } & 734.6 & -0.4 & - & -0.32 & -5.0 & 0.11 & 37.9 & 0.3 & 15.9 & 0.12 & 26.1 & 16 & -27333.3 & 54698.7 & $<10^{-4}$ \\
\hline & $<10^{-4}$ & $<10^{-4}$ & - & $<10^{-4}$ & 0.037 & $<10^{-4}$ & & & & & & & & & \\
\hline \multirow[t]{2}{*}{ M4.2 } & 742.7 & 60.4 & 57 & -0.70 & 4.9 & 0.05 & 40.3 & 134.5 & 19.5 & 0.11 & 25.5 & 17 & -27242.3 & 54518.5 & $<10^{-4}$ \\
\hline & $<10^{-4}$ & $10^{-3}$ & $<10^{-4}$ & $<10^{-4}$ & 0.057 & $10^{-3}$ & & & & & & & & & \\
\hline \multirow[t]{2}{*}{ M5.3 } & 741.3 & 61.0 & 62 & -0.65 & 25.3 & 0.07 & 39.5 & 170.7 & 48.0 & 0.23 & 25.0 & 17 & -27139.9 & 54313.8 & \\
\hline & $<10^{-4}$ & 0.006 & $<10^{-4}$ & $<10^{-4}$ & $<10^{-4}$ & 0.030 & & & & & & & & & \\
\hline \multirow[t]{2}{*}{ M6 } & 740.6 & 162.4 & 162 & -0.55 & - & 0.25 & 40.3 & 152.0 & - & 0.20 & 26.2 & 12 & -27309.8 & 54643.7 & $<10^{-4}$ \\
\hline & $<10^{-4}$ & $<10^{-4}$ & $<10^{-4}$ & $<10^{-4}$ & - & $<10^{-4}$ & & & & & & & & & \\
\hline \multirow[t]{3}{*}{ M7 } & 770.7 & 122.8 & 139 & - & - & 0.22 & 41.8 & 155.6 & - & 0.20 & 25.7 & 23 & -27222.7 & 54491.4 & $<10^{-4}$ \\
\hline & (6.4) & $(22.1)$ & (9.9) & - & - & $(0.03)$ & $0.09^{\mathrm{e}}$ & $0.11^{\mathrm{e}}$ & & $10^{-5} \mathrm{e}$ & $9.510^{-3}$ & & & & \\
\hline & $<10^{-4}$ & $<10^{-4}$ & $<10^{-4}$ & & & $<10^{-4}$ & & & & & & & & & \\
\hline
\end{tabular}

Correlations of random effects ${ }^{\mathrm{f}}$ in model M7: $\quad \rho($ a. b $)=-0.358 . \rho($ a. $f)=-0.364 . \rho($ b.f $)=0.84$

\begin{tabular}{|c|c|c|c|c|c|c|c|c|c|c|c|c|}
\hline $\begin{array}{l}\text { Cubic-spline } \\
\text { parameters }\end{array}$ & $\begin{array}{c}\mathbf{d}_{\mathbf{1}} \mathbf{x 1 0} \\
(1 / \mathrm{an})\end{array}$ & $\begin{array}{l}\mathbf{d}_{2} \mathbf{x 1 0} \\
\left(1 / \mathrm{an}^{2}\right)\end{array}$ & $\begin{array}{c}\mathbf{d}_{\mathbf{3}} \mathbf{x 1 0 ^ { 3 }} \\
\left(1 / \mathrm{an}^{3}\right)\end{array}$ & $\begin{array}{c}\mathbf{p}_{\mathbf{1}} \mathbf{x 1 0 ^ { 3 }} \\
\left(1 / \mathrm{an}^{3}\right)\end{array}$ & $\mathbf{p}_{2}$ & $\mathbf{p}_{3}$ & $\mathbf{p}_{4}$ & $\mathbf{p}_{5}$ & $\mathbf{p}_{6}$ & $\mathbf{p m}_{0}$ & $\mathbf{p m}_{1}$ & $\mathbf{p m}_{2}$ \\
\hline M7 (continued) & $\begin{array}{c}-2.714 \\
(1.525) \\
0.06\end{array}$ & $\begin{array}{c}1.097 \\
(0.226) \\
<10^{-4}\end{array}$ & $\begin{array}{c}-5.159 \\
(0.905) \\
<10^{-4}\end{array}$ & $\begin{array}{c}9.659 \\
(1.669) \\
<10^{-4}\end{array}$ & $\begin{array}{c}-7.638 \\
(1.548) \\
<10^{-4}\end{array}$ & $\begin{array}{c}6.008 \\
(1.477) \\
<10^{-4}\end{array}$ & $\begin{array}{c}-4.573 \\
(1.498) \\
0.002\end{array}$ & $\begin{array}{c}-0.976 \\
(2.051) \\
0.6\end{array}$ & $\begin{array}{c}-0.947 \\
(1.349) \\
0.9\end{array}$ & $\begin{array}{c}9.053 \\
(1.863) \\
<10^{-4}\end{array}$ & $\begin{array}{c}-5.545 \\
(1.995) \\
0.005\end{array}$ & $\begin{array}{c}1.604 \\
(1.656) \\
0.3\end{array}$ \\
\hline
\end{tabular}

Table 3 (see next page). 
Table 3 Models statistics and parameter estimates of mean ring density models. See Eq. 1 for models M1 to M3, Eq. 2 for models M4.2, M5.3 and M6, and Eqs. 3 and 4 for model M7. Unit applies for models M1 to M4.2, and is $\mathrm{kg} \cdot \mathrm{m}^{-3} \cdot \mathrm{mm}^{-0.5}$ for model M5.3. ${ }^{\mathrm{b}}$ Standard-deviations of random effects, ${ }^{\mathrm{c}}$ number of model parameters, ${ }^{\mathrm{d}} \mathrm{p}$-value of the likelihood ratio test (LRT) of nested model comparison (successive models in the table), ${ }^{\mathrm{e}}$ standard-errors for variances of random effects, ${ }^{\mathrm{f}}$ correlations between random effects were estimated after standardization of the associated fixed effects.

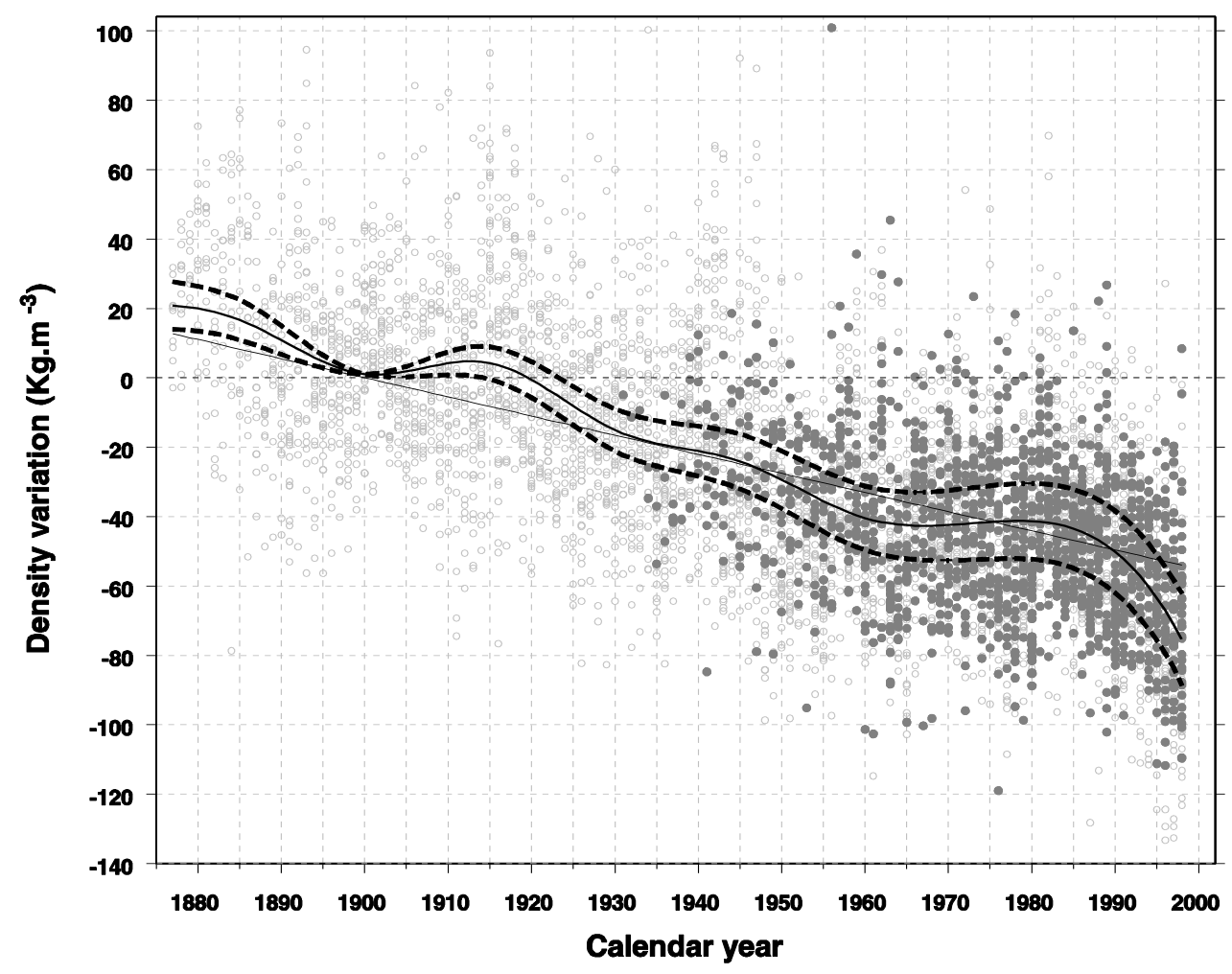

Fig. 3 Historical decrease in mean ring density of common beech in North-eastern France at constant ring size and tree radius. The mean linear trend (M6) and the historical variations (M7) are superimposed onto partial residuals of M7 where all effects but that of date were removed. Light grey open circles: rings of the older tree generation, dark grey full circle: younger tree generation. Full thick line: cubic-spline function of calendar year (M7, Table 3), thick dotted lines: 95\% bilateral confidence interval (details in Appendix of Bontemps et al. 2009), full thin line: linear historical trend (M6). 
ring density was thus very restricted for small trees $(10 \mathrm{~cm}$ in diameter), and increased to a point where the net trend in mean density was reduced by $50 \%$ for large trees (40 cm in diameter). On a relative scale, these centennial variations represented a decrease of -4.0 to $-7.0 \%$.

Since synchronous historical variations were detected between mean ring density and radial growth, these were amplified when the polynomial variations in mean ring density were combined to that resulting from polynomial variations in radial growth were combined (Table $\mathbf{2}$ and M7 in Table 3, Figure 5). The resulting net variation in mean ring density ranged between $-73 \mathrm{~kg} \cdot \mathrm{m}^{-3}$ at a tree radius of $5 \mathrm{~cm}$, and $-60 \mathrm{~kg} \cdot \mathrm{m}^{-3}$ at a radius of $40 \mathrm{~cm}(-10.0$ to $-8.2 \%$ on a relative scale). Nevertheless, the net variation was positive in the years 1910-1915, ranging between +5 and $+15 \mathrm{~kg} \cdot \mathrm{m}^{-3}$.

In conclusion, the historical increase in dominant radial growth had a positive effect on mean ring density that ranged between negligible at lower tree diameter $(10 \mathrm{~cm})$, and one half (linear decrease) or one third (polynomial fluctuations) of the historical decrease in ring density for the greatest sample diameters. It hence never counterbalanced the ring density decrease evidenced. 

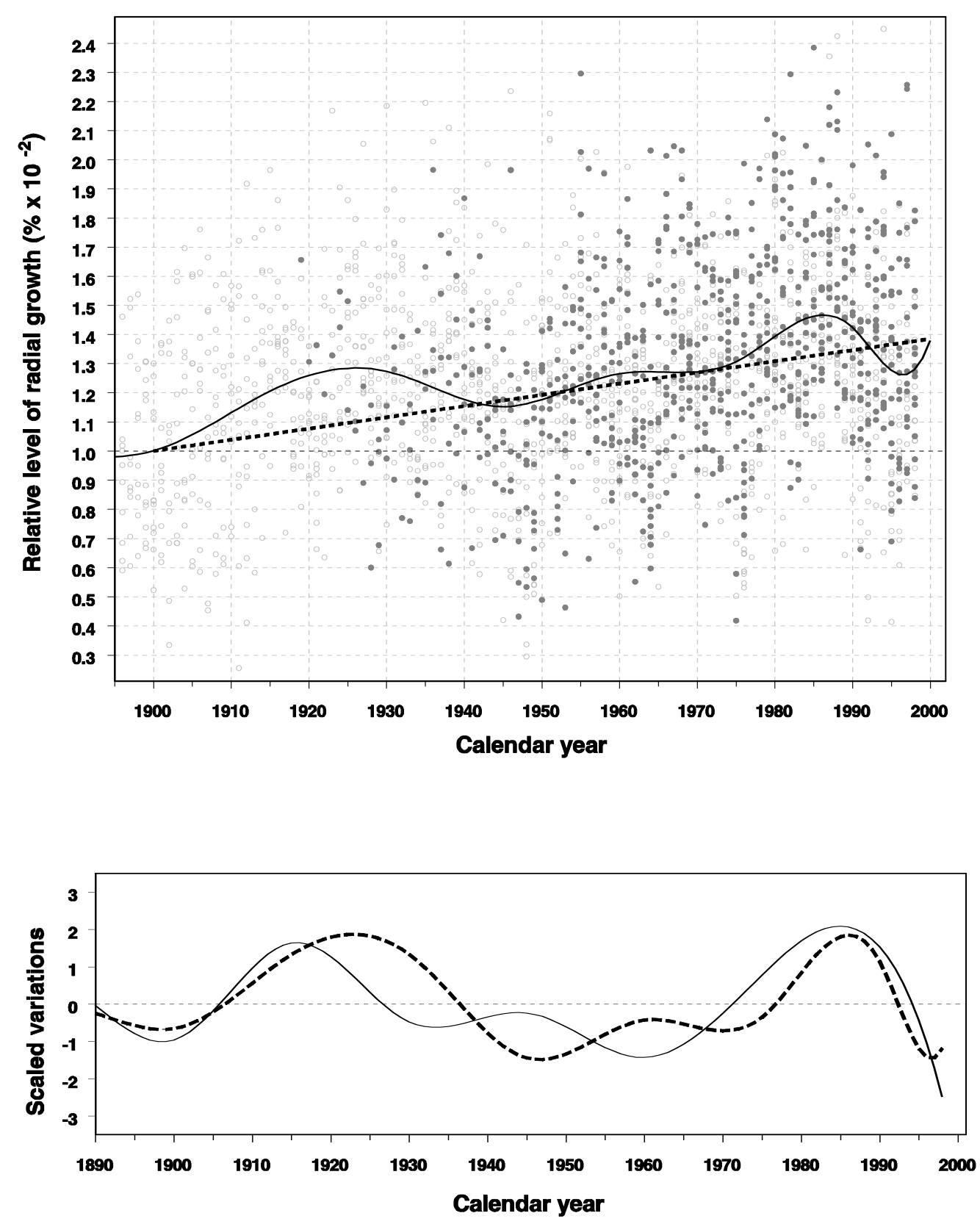

Fig. 4 Historical change in dominant radial growth at 1.30m of Common Beech in North-eastern France (a) and comparison of decennial variations in radial growth and mean ring density (b). Historical changes in radial growth were estimated on the same sample, by a linear (dotted lines) or a polynomial (full line) function of calendar year (see Table 2; Bontemps et al. 2010). Decennial variations in radial growth (b, dotted line) and mean ring density (full line) were detrended using a degree-3 ordinary polynomial function and were standardized (respective standard-deviations over the study period). 


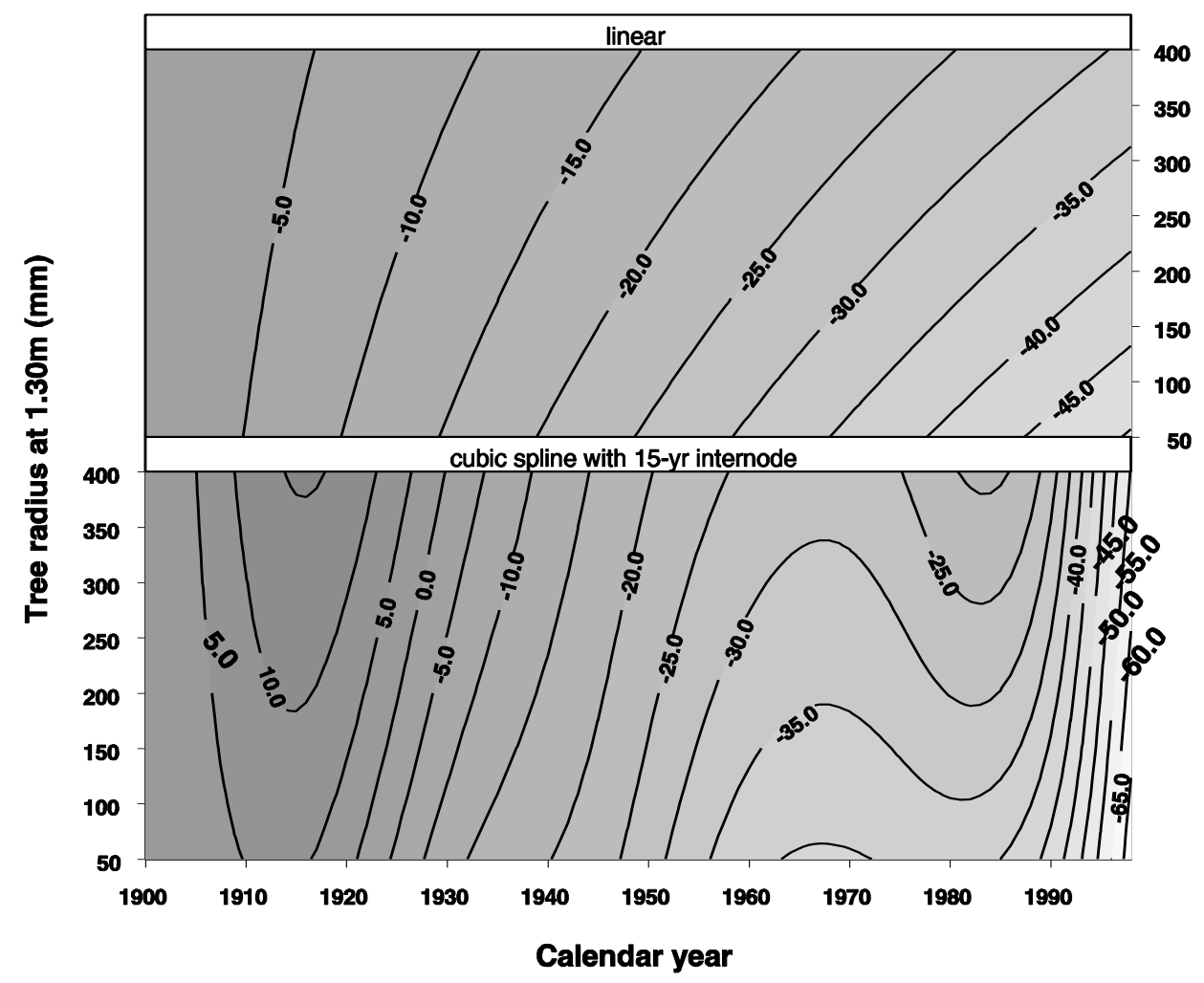

Fig. 5. Net historical variations in mean ring density $\left(\mathrm{kg}^{\left.-\mathrm{m}^{-3}\right)}\right.$ as a function of calendar year and tree radius after historical changes in radial growth at $1.30 \mathrm{~m}$ were taken into account (see Methods). These variations were computed from the historical decreases evidenced on mean ring density at constant tree radius $R$ and ring width $R W$ (this study), and from the historical increases in radial growth at $1.30 \mathrm{~m}$ (Bontemps et al. 2010) impacting mean ring density through the positive ring size-density relationship evidenced (M6 and M7, Table 3). Since this relationship increased with tree radius (interaction $R \cdot R W^{0.5}$ ), the effect of $R$ on these net variations was also included in this representation. Both linear (M6, top) and decennial fluctuations (M7, bottom) of mean ring density were plotted.

\section{DISCUSSION}

An objective of the present study was to estimate the historical change in mean ring density of a diffuse-porous hardwood (common beech), and to compare it with results are already available for a ring-porous hardwood (sessile oak, Bergès et al. 2000) and a softwood (Norway spruce, Franceschini et al. 2010) in a similar environmental context. The estimation of the historical change in ring density required to filter it out from the effects of developmental stage and radial growth, and a careful statistical control of these effects was crucial. A second objective was to evaluate the net historical change in density resulting from the additional effect of the historical change in radial growth as mean ring density depends on ring size. 


\section{Statistical estimation of the historical change in mean ring density at constant developmental stage and growth rate}

\section{Statistical effect of developmental stage and interpretation}

Tree radius at the time of ring formation proved to be more accurate a proxy than cambial age to represent the effect of developmental stage (Table 3). This effect was of decreasing magnitude with size. Relative to the sample mean tree density at the earliest developmental stage (radius of $4.7 \mathrm{~cm}$ ), the average effect corresponded to $-73 \mathrm{~kg} \cdot \mathrm{m}^{-3}$ for a radius of $30 \mathrm{~cm}$ i.e. a decrease by $-10 \%$ over developmental stage.

There is literature consensus regarding this effect on common beech. Preliminary findings reported a negative correlation between wood density over the last rings at $1.30 \mathrm{~m}$ and tree size (Keller et al. 1976). A systematic difference in mean density of heartwood and external rings was also found by Nepveu (1981b). In recent quantitative approaches, Govorčin et al. (1998) and Bouriaud et al. (2004) reported negative effects of cambial age of an average magnitude of -1.3 and $-1.0 \mathrm{~kg} \cdot \mathrm{m}^{-3} \cdot \mathrm{yr}^{-1}$, respectively $\left(-1.25 \mathrm{~kg} \cdot \mathrm{m}^{-3} \cdot \mathrm{yr}^{-1}\right.$ in our sample). The cambial age-density relationship was also found convex in Govorčin et al. (1998). As an anatomical interpretation, Gasson (1987) reported an increase in vessel diameter over more than 80 years in cambial age for this species.

\section{Statistical effect of growth rate $(R W)$ and interpretation}

A positive effect of ring width on mean ring density was evidenced (Figure 1b), and was found to be depending on tree size, leading to introduce a multiplicative interaction in the model (Figure 2, Table 3). A comparable formulation was used in Rozenberg et al. (2001) on Douglas fir. Assuming a tree radius of $20 \mathrm{~cm}$, the intensity of this effect $\left(18.5 R W^{0.5} \mathrm{~kg} \cdot \mathrm{m}^{-3}\right.$ after model M7) was quantified by doubling ring width from 1.5 to $3 \mathrm{~mm}$, and indicated an increase in mean ring density by $23 \mathrm{~kg} . \mathrm{m}^{-3}$. In a ring-porous hardwood such as in sessile oak, where the effect of ring width is more conspicuous, the same doubling in ring width (46 RW kg.m $\mathrm{m}^{-3}$ after Guilley et al. 1999) induced a $+70 \mathrm{~kg} \cdot \mathrm{m}^{-3}$ increase in mean ring density.

Reports in the literature are more uncertain as regards an effect of ring width in this diffuse-porous hardwood. Some correlation analyses based on specific gravity measurements did not show any relationship with ring width (Polge 1973, Keller et al. 1976). Based on microdensitometric measurements, Nepveu (1981b) identified a weak but positive relationship. Bouriaud et al. (2004) reported an absence of significant relationship between ring width and ring density. However, the corresponding sample included young trees (between 45 and 70 years old) with increments of $2.9 \mathrm{~mm}$ on average against $2.2 \mathrm{~mm}$ in our sample (Table 1), a level where the ring size-density relationship is dampened (Figures $\mathbf{1 b}$ and 2). The large between-tree variability of this relationship, found in our study and that of Bouriaud et al. (2004) also weakens the magnitude of the average size-density 
relationship over the sample. This relationship was even found negative for some trees in the sample, in line with Nepveu (1981b).

Investigations on wood anatomy provide support to a positive ring-size density relationship. Süss and Müller-Stoll (1972) and Gasson (1987) highlighted decreases in both size and surface proportion of vessels with ring width, while the proportion of fibres was found to increase. The number of vessels was also reported to decrease in Jacquiot et al. (1973). Alternatively, Sass and Eckstein (1995) reported a constant density of vessels along the ring, but decreasing in diameter.

\section{Between-tree variation in tree radius-density and $R W$-density relationships and interpretation}

Large between-tree variations in these relationships were found in the exploratory analysis, and these were confirmed in the random tree variations of the parameters associated to these relationships (Table 3). By computing the analysis of variance for mixed-effects models (Hervé 1999) in M6 and M7, we found that fixed effects accounted for around $19 \%$ of the total sample variation in mean ring density, in line with Bouriaud et al. (2004; 15\%). The tree random effects associated to the $R-D$ and $R . R W$ - $D$ relationships represented an additional $10 \%$ of variation (50\% of that of fixed effects), and up to $60 \%$ of this variation when the pure random tree effect was included (Eq. 1). These findings are in line with Le Moguédec et al. (2002) that found that the highest level of variability in the ring density of sessile oak was located at the tree level.

Such tree-level variations are usually attributed to genetic factors. Wood density hence shows the highest levels of heritability among phenotypic traits regardless of tree species (Kremer et al. 1994). On Douglas fir, Rozenberg et al. (2001) evidenced that including information on the genetic structure of populations led to greatly increase the accuracy of ring density models (from 6 to $33 \%$ in R2 with provenance to clonal levels).

\section{Historical change in mean ring density}

At constant tree radius and ring width, a decreasing trend of $-55 \mathrm{~kg} . \mathrm{m}^{-3}$ in mean ring density over the 20th century was evidenced (M6). This decrease reached $-75 \mathrm{~kg} \cdot \mathrm{m}^{-3}$ when the recent decline was taken into account (M7, Figure 3). On a relative scale, such findings are therefore remarkably similar to those of Bergès et al. (2000) on sessile oak (a ring-porous hardwood) and Franceschini et al. (2010) on Norway spruce (a softwood) that reported decreases by around $-5 \%$ in mean ring density over one century, although here of a sharper magnitude.

\section{Exclusion of confounding factors}

Developmental stage. Both The effects of developmental stage and calendar year induce negative variations in ring density over time. A confounding between these two factors may thus be possible. Accordingly, the estimate for the historical trend in mean ring density was twice as high in magnitude when the convexity of the developmental stage effect (Figure 1a) was accounted for (modelling step 2, Table 3) in the model. Here, the paired-plots structure of the sampling design proved especially 
useful for a statistical separation of these effects, as already evidenced for growth changes (Bontemps et al. 2009, 2012). By contrast, this estimation was poorly dependent on the proxy for developmental stage, since a difference by only $+4 \mathrm{~kg} \cdot \mathrm{m}^{-3}$ was found when tree radius (distance from the pith) was replaced by cambial age (age from the pith) in model M7 (not presented).

Duraminization processes. Heartwood formation is another factor of confusion that deserves attention. As a chemical maturation process of wood, including vessel filling by polyphenols and tannins (Hillis 1987, Guilley 2000 on Sessile oak), duraminization can increase the mean density of a ring over time. It may thus amplify or even cause the apparent decrease reported in ring wood density in our study. Moreover, since a proxy for this phenomenon would be an age from the cambium (direction opposed from cambial age), and since all trees were sampled at a single date, there is intrinsic confusion between this putative effect and the historical decrease reported.

First, this process may however be of late occurrence, and of restricted impact on common beech. Chemical analyses performed on 60-year old trees to discriminate heart- and sapwood proved unsuccessful (Bartelink 1997). Nečesaný (1958) also reported no change in activity of parenchyms before 50-70 years after ring formation. Sapflow analyses (Schäfer et al. 2000) revealed a constant flux in a radial direction from $2 \mathrm{~cm}$ away from the cambium to the pith (see also Møller and Müller 1938, cited by Hillis 1987). These studies are in accordance with a formation of heartwood that would not occur before 80-100 years (Hillis 1987), and even up to 120-150 years (Nečesaný, 1958). Thus the impact on the present centennial chronology (Figure 3) should be restricted.

Second, two properties of the statistical model lead to discard a residual heartwood-based interpretation of the historical trend reported. First, we allowed a between-tree variation in the effect of developmental stage, much more likely to capture heartwood formation effects, occurring at tree scale, than the average historical change we estimated. Second, assuming that the ring size-density relationship is related to decline in vessel frequency/size along the ring, and that heartwood formation impact on wood density increases with vessel lumen proportion in the ring, the $R-R W$ interaction (less intense for earlier developmental stages, i.e. rings matured for long) may be reasonably interpreted as the footprint of this maturation.

\section{Net historical change in mean ring density including the historical increase in radial growth}

Since we evidenced a positive effect of ring width on wood density, we investigated the additional effect of historical increases in radial growth evidenced over this sample (Bontemps et al. 2010) on mean ring density. Due to the $R-R W$ interaction, tree radius was an additional factor to consider on these net historical variations (Figure 5). As a main outcome, the centennial decrease in mean ring density persisted, and was comprised in a range of -4 to $-7 \%$ in the linear framework ( -8 to $-10 \%$ in the polynomial framework), depending on tree radius. For a maximum tree radius of $40 \mathrm{~cm}$, the compensation amounted to $+25 \mathrm{~kg} \cdot \mathrm{m}^{-3}$ (for a mean trend of $-55 \mathrm{~kg} \cdot \mathrm{m}^{-3}$, M6 and Figure 5), i. e. a relative compensation of a maximum $43 \%$. 
In a context of historical forest growth increases, a stable positive $R W$ - $D$ relationship over time implies an increase in ring density. It may thus be hypothesized that the historical decrease in ring density at constant ring width actually corresponds to a down-regulation exerted on the positive $R W-D$ relationship, in order to maintain density more or less constant. Such view may be supported by the early work of Bergès et al. on Sessile oak (2000; $\mathrm{a}+66 \% R W$ over one century corresponded to +25 $\mathrm{kg} . \mathrm{m}^{-3}$ in mean ring density following the $R W-D$ relationship evidenced. The parallel decrease in mean ring density at constant ring width was around $-29 \mathrm{~kg} . \mathrm{m}^{-3}$ ). The hypothesis however does not hold here, as a net decrease in mean ring density was ascertained. This may be even more obvious in Franceschini et al. (2010) on Norway spruce, where a similar $-5 \%$ decrease in mean ring density was observed, despite the $R W-D$ relationship is negative, suggesting an even stronger decrease in mean ring density following past radial growth increases in this species (Badeau et al. 1996). Hence, common beech is a tree species in which wood has behaved like imperfect foam over the past decades, 'expanding' fast, but not 'distending' accordingly. A major consequence concerns changes in biomass sequestration. The net decrease in mean ring density of, say $-8.0 \%$ for trees of $40 \mathrm{~cm}$ in diameter $(-60$ kg. $\mathrm{m}^{-3}$, Figure 5) provides an idea of the temporal centennial bias induced from predicting the biomass change from the volume change under a constant wood density assumption. Significant variations in wood density over ontogeny ( $-10 \%$ for common beech, see Results) also challenge this assumption. Obviously, this has consequences for evaluations of carbon sequestration that usually assume wood density to be a species constant (Karjalainen et al. 2003) and this calls for extending the analyses to wider sets of tree species and regions.

\section{Historical decreases in wood density and their origin}

There may be some degree of generality in this phenomenon, as it has been observed at different locations worldwide, including at high latitudes all over the Northern hemisphere (Briffa et al. 1998), and in temperate areas of Northern America (Conkey 1988) and Europe (Bergès et al. 2000, Franceschini et al. 2010, this study). In addition, the latter studies performed in the same regional area confirm that homoxylous softwood, ring-porous and diffuse-porous hardwoods are similarly affected.

Climatic studies of maximum latewood density (Briffa et al. 1998, Conkey 1988) and mean ring density (Franceschini et al. 2012) have shown that this density decrease comes along with a loss of sensitivity to temperatures over the second half of the century - a phenomenon that has been termed 'divergence' (d'Arrigo et al. 2008) - suggesting that the cause is not climatic. The role of anthropogenic pollution (Conkey 1988, Franceschini et al. 2010) and reduction of incoming solar radiation (global dimming, d'Arrigo et al. 2008) has been discussed. In the present case, North-eastern France has been affected by climate warming (Moisselin et al. 2002), significant levels of nitrogen deposition (Croisé et al. 2005) and increases in the level of atmospheric $\mathrm{CO}_{2}$ concentration, making it difficult to disentangle these factors.

As an alternative hypothesis, however, insight from the present study on common beech, and from Badeau et al. (1996) and Franceschini et al. (2010) on Norway spruce may also suggest a more direct 
temporal trade-off between growth and density, as evidenced on a seasonal time scale by Bouriaud et al. 2005. This would result in what we termed a 'foam-like' behaviour. Progress on the issue should come from anatomical explorations of wood formation and maturation characteristics.

\section{Conclusions}

For the first time, long-term changes in wood density were investigated in a diffuse-porous hardwood, represented by common beech. We evidenced a mean historical trend in mean ring density of -55 $\mathrm{kg} . \mathrm{m}^{-3}$ over the 20th century $(-7.5 \%)$, at constant ring width and tree radius. Decennial oscillations in mean ring density were observed, and paralleled those observed in radial growth. The decrease amounted to $-75 \mathrm{~kg} . \mathrm{m}^{-3}$ when these oscillations were taken into account. Increased radial growth of $+50 \%$ over the past century also induced a restricted increase in mean ring density. The resulting trend in mean ring density remained negative $(-5.5 \%$ on average).

Tree rings in common beech, therefore, have exhibited foam-like behaviour over the past decades (strong expansion, and partial corresponding dilatation), which suggests that biomass sequestration does not follow growth trends over time. Since decreasing trends in wood density have been identified over several continents in the boreal and temperate areas, the phenomenon may have a large degree of generality, and would thus be unduly neglected in carbon accounting approaches.

\section{Acknowledgments}

The authors gratefully thank an anonymous reviewer and the Editor-in-chief of this journal for their helpful comments to clarify a previous version of this manuscript. We also wish to thank Dr Frédéric Mothe (INRA) for his advice on microdensitometric measurements, and Dr Jean-Michel Leban and Dr Tony Franceschini (INRA) for stimulating discussions on wood density variations and their determinants. The first author dedicates this article to Suzanne Bontemps born Tisserand (d. 13 March 2012). 


\section{Reference list}

Badeau V, Becker M, Bert D, Dupouey J-L, Lebourgeois F, Picard J-F (1996) Long-term growth trends of trees: ten years of dendrochronological studies in France. In: Spiecker $\mathrm{H}$, Mielikaïnen K, Köhl M, Skovsgaard JP (eds) Growth trends in European forests, EFI Research Report 5, Springer, pp 167-181

Bartelink HH (1997) Allometric relationships for biomass and leaf area of beech (Fagus sylvatica L.). Ann For Sci 54:39-50

Bergès L, Dupouey J-L, Franc A (2000) Long-term changes in wood density and radial growth of Quercus petraea Liebl. in northern France since the middle of the nineteeth century. Trees $14: 398-408$

Boisvenue C, Running SW (2006) Impacts of climate change on natural forest productivity - evidence since the middle of the 20th century. Glob Change Biol 12:862-882

Bontemps J-D, Hervé J-C, Dhôte J-F (2009) Long-term changes in forest productivity: a consistent assessment in even-aged stands. For Sci 55:549-564

Bontemps J-D, Hervé J-C, Dhôte J-F (2010) Dominant radial and height growth reveal comparable historical variations for common beech in north-eastern France. For Ecol Manag 259:14551463

Bontemps J-D, Hervé J-C, Duplat P, Dhôte J-F (2012) Shifts in the height-related competitiveness of tree species following recent climate warming and implications for tree community composition: the case of common beech and sessile oak as predominant broadleaved species in Europe. Oikos 121:1287-1299

Bouriaud O, Bréda N, Le Moguédec G, Nepveu G (2004) Modeling variability of wood density in beech as affected by ring age, radial growth and climate. Trees 18:264-276

Bouriaud O, Leban J-M, Bert D, Deleuze C (2005) Intra-annual variations in climate influence growth and wood density of Norway spruce. Tree Physiol 25:651-660.

Briffa KR, Schweingruber FH, Jones PD, Osborn TJ, Shiyatov SG, Vaganov EA (1998) Reduced sensitivity of recent tree-growth to temperature at high northern latitudes. Nature 391:678-682 
Conkey LE (1988) Decline in old-growth red spruce in western Maine: an analysis of wood density and climate. Can J For Res 18:1063-1068

Croisé L, Ulrich E, Duplat P, Jaquet O. 2005 Two independent methods for mapping bulk deposition in France. Atm Env 39:3923-3941.

Davidian M, Giltinan DM (1995) Nonlinear models for repeated measurement data. Chapman \& Hall, London

D'Arrigo R, Wilson R, Liepert B, Cherubini P (2008) On the 'divergence problem' in Northern forests: a review of the tree-ring evidence and possible causes. Glob Plan Change 60:289-305.

Duplat P, Tran-Ha M (1997) Modélisation de la croissance en hauteur dominante du chêne sessile (Quercus petraea Liebl) en France. Variabilité inter-régionale et effet de la période récente (1959-1993). Ann For Sci 54:611-634

Franceschini T, Bontemps J-D, Gelhaye P, Rittié D, Hervé J-C, Gégout J-C, Leban J-M (2010) Decreasing trend and fluctuations in the mean-ring density of Norway spruce through the twentieth century. Ann For Sci 67. doi:10.1051/forest/2010055

Franceschini T, Bontemps J-D, Leban J-M (2012) Transient historical decrease in earlywood and latewood density and unstable sensitivity to summer temperature for Norway spruce in northeastern France. Can J For Res 42:219-226.

Gasson P (1987) Some implications of anatomical variations in the wood of pedunculate oak (Quercus robur L.), including comparisons with common beech (Fagus sylvatica L.). IAWA Bulletin 8:149-165

Gonçalves JLM, Stapea JL, Laclau J-P, Smethurst P, Gavad JL (2004) Silvicultural effects on the productivity and wood quality of eucalypt plantations. For Ecol Manag 193:45-61

Govorčin S, Sinkovik T, Trajkovic J (1998) Distribution of properties in use for oak, beech and firwood in a radial direction. Dvrna Industrija 49:199-204

Guilley E (2000) La densité du bois de Chêne sessile (Quercus petraea Liebl.): Elaboration d'un modèle pour l'analyse des variabilités intra- et inter- arbre ; origine et évaluation non destructive de l'effet "arbre" ; Interprétation anatomique du modèle proposé. Thèse de Doctorat, ENGREF, Nancy 
Guilley E, Hervé J-C, Huber F, Nepveu G (1999) Modelling variability of within-ring density components in Quercus petraea Liebl. with mixed-effects models and simulating the influence of contrasting silvicultures on wood density. Ann For Sci 56:449-458

Guilley E, Hervé J-C, Nepveu G (2004) The influence of site quality, silviculture and region on wood density mixed model in Quercus petraea Liebl. For Ecol Manag 189:111-121

Hervé J-C (1999) Mixed-effects modelling of between-tree and within-tree variations: application to wood basic density in the Stem. Contract FAIR CT96-1915. Product properties predictionimproved utilization in the forestry-wood chain applied on spruce sawnwood. Subtask 2.1. CPL, Newbury.

Hillis WE (1987) Heartwood and tree exudates. Wood Science, Springer, Berlin Heidelberg NewYork

Jacquiot C, Trenard Y, Dirol D (1973) Atlas d'anatomie des bois des angiospermes (essences feuillues). Centre Technique du Bois, Paris, 175 p.

Karjalainen T, Pussinen A, Liski J, Nabuurs GJ, Eggers T, Lapvetelainen T, Kaipainen T (2003) Scenario analysis of the impacts of forest management and climate change on the European forest sector carbon budget. For Pol Econ 5:141-155

Karlman L, Mörling T, Martinsson O (2005) Wood density, annual ring width and latewood content in Larch and Scots Pine. Euras J For Res 8:91-96

Keller R, Le Tacon F, Timbal J (1976) La densité du bois de hêtre dans le Nord-Est de la France. Influence des caractéristiques du milieu et du type de sylviculture. Ann For Sci33:1-17

King DA, Davis SJ, Tan S, Noor NSMD (2006) The role of wood density and stem support costs in the growth and mortality of tropical trees. J Ecol 94:670-680

Kremer A (1994) Diversité génétique et variabilité des caractères phénotypiques chez les arbres forestiers. Gen Selec Evol 26:105-123

Lange K (1999) Numerical analysis for statisticians. Springer, New-York Berlin Heidelberg. 
Lebourgeois F, Becker M, Chevalier R, Dupouey J-L, Gilbert J-M (2000) Height and radial growth trends of Corsican pine in western France. Can J For Res 30:712-724.

Le Moguédec G, Dhôte J-F, Nepveu G (2002) Choosing simplified mixed models for simulations when data have a complex hierarchical organization. An example with some basic properties in Sessile oak wood (Quercus petraea Liebl.). Ann For Sci 59:847-855

Lindström MJ, Bates DM (1990) Nonlinear mixed effect models for repeated measures data. Biometrics 46:673-687

Mäkinen H (1997) Reducing the effects of disturbance on tree-ring data using intervention detection. Scand J For Res 12:351-355

Moisselin JM, Schneider M, Canellas C, Mestre O (2002) Les changements climatiques en France au XXe siècle. Etude des longues séries homogénéisées de données de température et de précipitations. La Météorologie 38:45-56.

Møller CM, Müller D (1938) Aanding i aeldre Stammer. Forstlige Forsøgsvaesen i Danmark 15:113138

Mörling T (2002) Evaluation of annual ring width and ring density development following fertilisation and thinning of Scots pine. Ann For Sci 59:29-40

Mothe F, Duchanois G, Zannier B, Leban J-M (1998) Analyse microdensitométrique appliquée au bois : méthode de traitement des données utilisée à l'inra-ERQB (programme Cerd). Ann For Sci 55:301-313

Nepveu G (1981a) Propriétés du bois de hêtre, 377-396. In: Teissier du Cros E (ed) Le Hêtre. INRA, Paris

Nepveu G (1981b) Prédiction juvénile de la qualité du bois de hêtre. Ann For Sci 38:425-447.

Nepveu G (1999) Possible effects on wood quality to expect from accelerating tree growth in Europe: tentative answers and questions to accommodate. In: Karjalainen, T. Spiecker, H. Laroussinie, O. (eds) Causes and consequences of accelerating tree growth in Europe, EFI proceeding n²7, EFI, Joensuu, pp 207-216 
Nečesaný V (1958) Zmena vitality parenchymatickych bunek jako fysiologicky zaklad tvorby jadra buku. Drevarsky Vyskum 3:15-23.

Peltola H, Kilpeläinen A, Sauvala K, Räisänen T, Ikonen V-P (2007) Effects of early thinning regime and tree status on the radial growth and wood density of Scots pine. Silv Fenn 41:489-505

Pinheiro JC, Bates DM (2000) Mixed-effects models in S and S-PLUS. Springer-Verlag, New-York

Polge H (1973) Etat actuel des recherches sur la qualité du bois de hêtre. Bulletin technique de l'ONF 4:13-22

Polge H, Nicholls JWP (1972) Quantitative radiography and the densitometric analysis of wood. Wood Sci 5:51-59

Rao RV, Aebischer DP, Denne MP (1997) Latewood density in relation to wood fiber diameter, wall thickness, and fibre and vessel percentages in Quercus robur L. Iawa J 18:127-138

Rosell JA, Olson ME (2007) Testing implicit assumptions regarding the age vs. size dependence of stem biomechanics using Pittocaulon (Senecio) praecox (Asteraceae). Am J Bot 94:161-172

Rozenberg P, Franc A, Bastien C, Cahalan C (2001) Improving models of wood density by including genetic effects: A case study in Douglas-fir. Ann For Sci 58:385-394

Sass U, Eckstein D (1995) The variability of vessel size in beech (Fagus sylvatica L.) and its ecophysiological interpretation. Trees 9:247-252

Schäfer KVR, Oren R, Tenhunen JD (2000) The effect of tree height on crown level stomatal conductance. Plant Cell Env 23:365-375

Sharma RP, Brunner A, Eid T (2012) Site index prediction from site and climate variables for Norway spruce and Scots pine in Norway. Scand J For Res 27:619-636

Spiecker H, Mielikäinen K, Köhl M, Skovsgaard JP (eds) (1996) Growth trends in European forests, Research report n ${ }^{\circ}$. Springer, Berlin Heidelberg

Spiecker H (1999) Growth trends in European forests - Do we have sufficient knowledge? In: Karjalainen, T. Spiecker, H. Laroussinie, O. (eds) Causes and consequences of accelerating tree growth in Europe, EFI proceeding n²7, EFI, Joensuu, pp 157-169 
Süss H, Müller-Stoll WR (1972) Relations between the development of some wood features and the ring width in Beech (Fagus silvatica L.) Holz als Roh- und Verkstoff 30:342-346

Venet J (1963) Etudes de qualité de dix échantillonnages de bois d'essences diverses provenant de Corse, Ecole Nationale des Eaux et Forêts, Nancy

Zhang SY (1995) Effect of growth rate on wood specific gravity and selected mechanical properties in individual species from distinct wood categories. Wood Sci Tech 29:451-465

Zobel B (1992) Silvicultural effects on wood properties. IPEF International Piracicaba 2:31-3 


\section{Electronic supplementary material}

Online Resource 1. Historical variations in mean ring density at constant developmental stage and ring width. Detailed results of the statistical modelling steps (see section 'Materials and Methods', subsection 'Statistical modelling steps').

\section{Modelling step 1}

The effects of cambial age $C A$ and the interaction $C A . R W$ (Eq. 1) were highly significant. Consistent with Figures 1 and 2, the effect of $C A$ was negative, and that of the interaction between $C A$ and $R W$ were found positive. The pure effect of $R W$ was in limit of significance (M1, Table 3), indicating a possible over-parameterization in the effect of $R W$. The standard-deviations of random effects were very important in magnitude (parameter means and standard-deviations in Table 3), and attested of strong between-tree variations in the $C A-D$ and $R W-D$ relationships.

A decrease in AIC by -66 points was observed when $C A$ was replaced by tree radius $R$, suggesting that $R$ was a better proxy for developmental stage than $C A$ (M2, Table 3). This was also confirmed by a reduction of one half in the standard-deviation of the random effect of parameter $b$ that indicated a more stable relationship with this proxy. Tree radius was thus retained in the following. The pure effect of $R W$ was more significant in M2 and other effects remained very significant, and constant in sign.

The introduction of a linear effect of calendar year $t$ (M3) led to a significantly better model (Table 3). A decrease by 16 points in AIC was observed. The effect of date was found negative $\left(-32 \mathrm{~kg} \cdot \mathrm{m}^{-3}\right.$ over 100 years) and very significant. A logical decrease in the effect of tree radius (positively correlated with calendar year: 0.60) was observed.

\section{Modelling step 2}

Residuals of model M3 against R revealed a convexity, and the functions considered for $f_{1}$ were tested (Eq. 2). Both forms significantly improved the model accuracy (Table 3). Strong decreases in AIC by -130 and -180 points were observed with the hyperbolic (model M4.1, not presented) and exponential (model M4.2, Table 3) effects of $R$, respectively. Since the effect of $R$ and $t$ were both negative on mean ring density, accounting for this curvature also had a significant impact on the magnitude of the historical trend that was decreased down to $-70 \mathrm{~kg} \cdot \mathrm{m}^{-3}$ over 100 years, corresponding to a rough $-10 \%$ relative to the sample mean ring density. Again, the pure effect of $R W$ was in limit of significance. Model M4.2 was retained in the following.

The different functions of $R W$ tested led to contrasted results, from over +150 points in AIC for the asymptotic effect $1 / R W$ (M5.1, not presented) to over -200 points for the effect of $R W^{0.5}$ (M5.3, Table 3). The effect of $\ln R W$ (M5.2, not presented) led to an intermediate accuracy, equivalent to that of M4.2 ( +4 points AIC). The curvature of the effect of $R W$ was thus confirmed, and induced a small but 
logical decrease in the historical trend on mean ring density $\left(-65 \mathrm{~kg} \cdot \mathrm{m}^{-3}\right.$ over $100 \mathrm{yrs}$ in M5.3, Table $3)$.

\section{Modelling step 3}

A swap in the significance of the pure effect of $R W$ and the interaction $R \cdot R W$ was observed in M5.3. Since these effects were never simultaneously significant in the previous models, we simplified model M5.3. However, the between-tree variation in the associated parameters remained of high magnitude, implying to perform comparisons with and without random effects. When only fixed effects for parameters e and $\mathrm{f}$ were considered, the suppression of the interaction term $R \cdot R W^{0.5}$ (f) led to a significantly worse fitting accuracy (+350 points in AIC, $\left.p<10^{-4}\right)$, which was not the case when removing the pure effect of $R W$ (e, +2.8 points in AIC, $p=0.04$, not presented). When random effects were reintroduced, the suppression of any of these effects was highly significant ( $p<10^{-4}$ in both cases) suggesting that most of these differences were generated by suppression of random effects. However, again, the model including the multiplicative term $R . R W^{0.5}$ was significantly more accurate $(-180$ points in AIC). Hence, we retained the multiplicative effect $R \cdot R W^{0.5}$ (M6) that was much more parsimonious (12 instead of 17 parameters, due to the associated decrease in rank of the variancecovariance matrix of random effects), despite its AIC and likelihood were worse than in model M5.3 (Table 3). All parameters were highly significant in model M6. The historical trend was estimated to $55 \mathrm{~kg} \cdot \mathrm{m}^{-3}$ over 100 years.

Residuals of model M6 against calendar year revealed temporal fluctuations. The introduction of the cubic-spline function of calendar year ( $f_{3}$ of Eq. 3, M7) led to a decrease by over -150 points in AIC $\left(p<10^{-4}\right)$. Residuals of this final model plotted against predictions did not reveal any bias in the model. The test of normality was also satisfied. 